NBER WORKING PAPER SERIES

\author{
FOLLOWING IN HER FOOTSTEPS? \\ WOMEN'S CHOICES OF COLLEGE \\ MAJORS AND FACULTY GENDER \\ COMPOSITION
}

Brandice J. Canes

Harvey S. Rosen

Working Paper No. 4874

\author{
NATIONAL BUREAU OF ECONOMIC RESEARCH \\ 1050 Massachusetts Avenue \\ Cambridge, MA 02138 \\ October 1994
}

We are grateful to John Abowd, Elizabeth Bogan, Ronald Ehrenberg, Henry Farber, Daniel Hamermesh, Douglas Holtz-Eakin, Robert Hutchens, Alan Krueger, Jolın Penrod, and Robert Stern for many useful suggestions. We also thank the following individuals for their assistance in obtaining the data: Anthony Broh and Dona Vukson of Princeton University; Cynthia Beaver and Pat MacIntosh of the University of Michigan; and Gerald Adams and Jenny Allen of Whittier College. This research was funded in part by grants from Princeton's Woodrow Wilson School and the Center for Economic Policy Studies. The data were analyzed using STATA, and are available upon request to the authors. This paper is part of NBER's research program in Labor Studies. Any opinions expressed are those of the authors and not those of the National Bureau of Economic Research.

(c) 1994 by Brandice J. Canes and Harvey S. Rosen. All rights reserved. Short sections of text, not to exceed two paragraphs, may be quoted without explicit permission provided that full credit, including $\odot$ notice, is given to the source. 
NBER Working Paper \#4874

October 1994

\title{
FOLLOWING IN HER FOOTSTEPS? \\ WOMEN'S CHOICES OF COLLEGE \\ MAJORS AND FACULTY GENDER \\ COMPOSITION
}

\begin{abstract}
It is frequently asserted that a college's female undergraduate enrollment in the sciences and engineering can be increased by raising female representation on the faculties in these areas. Despite the widespread acceptance of this proposition, it does not appear to have been subjected to any kind of serious statistical analysis. In this paper, we assemble panel data from three rather difierent educational institutions, and use them to examine the relationship between the gender composition of the students in an academic department and the gender composition of its faculty at the time the students were choosing their majors. We find no evidence for the conventional view that an increase in the share of females on a department's faculty leads to an increase in its share of fernale majors.
\end{abstract}

Brandice J. Canes

Graduate School of Business

Stanford University

Stanford, CA $94305-5015$
Harvey S. Rosen

Department of Economics

Princeton University

Princeton, NJ 08544

and NBER 


\section{Introduction}

In recent years, considerable concern has been expressed over the dearth of female scientists and engineers in the United States. This concern has focused attention on the fact that female college undergraduates are much less likely to major in science, mathenatics, and engineering than their male counterparts. One common belief is that increasing the number of female faculty in these fields would increase the number of females majoring in them. This belief appears to have influenoed public policy. For example, the National science Foundation has instituted a "Visiting Professocships for Wanen" program that provides grants to enable women scientists and engineers to serve as visiting professors at U.S. academic institutions. One abjectlve of the program is "To encourage female students to pursue careers in science and engineering by providing greater visibility for women scientists and engineers in inchistry, govermment, and academic institutions."

This notion has also taken hold in a nuber of ectucational

institutions. For example, a recent report at Prinoetan University entitled A Procram for the Recultment and Retention of ramen Faculty in Science and Engineering asserted that Prinoeton's "ability to attract and retain wamen students" would be "profoundly affected" by an increase in the number of female faculty in science and engineering (Girgus [1992, p.51). Dartmarth college has established a women in science Project whose purpose is to increase the percentage of women pursuing science majors by hiring more women faculty in the sciences. Similarly, the Provost of Yale 
University recently indicated that, in order to attract more wamen to math and science, universities should think about changing their hiring practices in ways that would lead to increases in the muber of female faculty members (New York Times, Jaruary 24, 1993, p. 23).

Given the academic commity's widespread acceptance of this view, we were surprised when we were umable to find any serious enpirical support whatsoever for the assertion that the gender composition of an acadenic department affects the gender camposition of its majors. The purpose of this paper is to investigate this hypothesis ecanometrically. To do so, we obtained fram three different academic institutions data that track the mubers of female faculty and students across departments and over time. In general, we find no evidence for the conventional view that an increase in the share of females on a department's facilty leads to an increase in its share of female undergraduate majors. Hence, university administrators who seek to increase fenale enrollments in particular departments by incucing an increase in female faculty may find their efforts to be of no avail.

\section{Backgraund}

The notion that an undergraduate waman's choice of major is affected by the faculty's gender camposition appears to be based on the concept of a role model, defined as an individual who has "skills or qualities that [another] lacks and yet admires and wishes to emulaten (Anderson and Ramsey (1990, p. 183]). Young wamen are argued to need female role models because a person is most likely to emulate scmeone who appears similar to himself or herself in external characteristics.1 
Another argument for the need for female role models relates to the traditional role of wamen in American society. Acoording to this view, the character attributes necessary for professional achievement are incompatible with traditional feminine qualities, so that a young woman with serious career ambitions needs female role models to demonstrate that sucoess is possible. Thus, Tilghman [1993] argues that "all but the most determined wamen will tend to gravitate to the envirarment which is most positive and rewarding, and that tends to be where other wamen have already led the way." Acoording to Fox [1974, p.19], "The deviations fran normative female marital and familial patterns that are typical of women Fh.D.s may locm as more significant where female faculty is small." Similarly, Lafortume [1990, p.273] asserts that, "Only an increase in the rumber of wamen in scientific careers, and/or the teaching of math and science at advanced levels, will change the masculine social image associated with these fields, and enoourage moce girls to enter them."2 What evidence is there for the importance of role models? Kost of it comes from surveys that ask young women what factors determine the careers for which they are preparing. For example, Basow and Howe [1980, p.571] surveyed a grap of college students, and on the basis of the responses concluded that "female models are particularly important for female college students in their career decisions, especially mothers and female teachers." similarly, after interviewing a group of collego-bound female high-sctiool seniors, Mature and Piehl [1978, p.181] concluded that "ore of the major barriers" to women's sucoess in science is that girls "perceive that preparation for science careers is too difficult because they lack awareness of sucoessful women scientists." on the basis of the 
Malure-Piehl survey, Betz and Fitzgerald [1987, pp.70-71] argue that "there is evidence that the relative lack of female faculty is a deterrent to wanen's educational an (sic) career pursuits, particularly in science." However, the fact that individuals in a survey assert that some factor is the cause of their behavior does not mean that it necessarily is. In amy case, other surveys came to the opposite canclusion. Hackett, Esposito and O'Halloran [1989, p.177] surveyed a group of college wamen and concluded that "perceived role model influences... are not pramising explanatory variables for nontraditional and science-related college-major choices."

A more serious attempt to establish a link between female faculty role models and female student enrollment was made by Fox [1974]. For several universities, he computed the correlation between the mmber of wamen faculty and nmber of women undergraduates in major acadenic divisions. ${ }^{3}$ He found a positive correlation, and interpreted this as surport for the notion that same-gender role models affect undergractuate choice of major. However, Fox's finding really tells us nothing about whether increasing the female faculty representation in a department would increase female undergraduate enrollment. To examine the validity of such a claim, one would have to analyze the relation across time between the gender camposition of faculty and the gender camposition of students. In contrast, Fox examines the relationship at a given point in time. The finding of a positive correlation in a cross section might be we simply to the fact that women gravitate to certain coapations and the associated courses of study because of altaral influences: "[C]hildren may internalize traditional notions of sex roles, accept these aularal sex 
stereotypes as fact, and eventually choose ooapations that conform to these stereotypes" (Corcoran and courant [1985, p.275]).

While arr focus is on the decisians of college students, there has been same closely related work on the choice of carses by pre-oollege girls. Here as well female role models have been assigned a key role. However, we have not been able to find any more ocarpelling evidence in the high school than in the college context. Smith and Exb [1986, p.673] claim that "the use of wonen science career models may positively affect both enrollment in science carses by girls entering high school and their personal consideration of a science career." This conclusion was drawn on the basis of an experiment in which one graup of students was exposed to same women scientists over a period of time and a control graup was not. The students were surveyed before and after the test. In the pre-test stage, the groups were similar in their responses to questions about wamen in science. In the post-test stage, the experimental group had a more positive attitude toward wamen in science. There was, however, no evidence on whether the girls in the experimental grap subsequently were actually more likely to enroll in science courses. 4

In sumary, the effects of same-gender role models have been studied in the psyctological and sociological literatures on education and career development. 5 While the verdict is not unanimous, the general view is that role models affect wamen's educational and career choices. However, most of the eviderce is based either an case studies ar surveys. We have found no atteripts explicitly to relate changes in the rumber of female role models to changes in young wamen's participation in various erdeavors. 


\section{Data}

The data for this study were collected fram three schools, Princeton University, the University of Michigan at Ann Arbor, and Whittier college. one reason these institutions were selected is simply that they were willing to give us the information we requested-a number of other schools we approached were urwilling or urable to provide the necessary information. ${ }^{6}$ Their selection was also influenced by our desire to obtain same diversity with respect to type of institurion, and hence to determine whether the role model theory applies in same settings and not in others. Princeton is a highly selective ${ }^{7}$ private research university whose undergrachate enroliment (abourt 4,500 students) is relatively small for a research university. Michigan is a selective public research university with a much larger undergraduate student body, abourt 22,000 students. Whittier is a small $(2,000$ student), private, liberal arts oollege that puts much less emphasis on research than Princeton and Michigan, and which has less stringent admissions requirements than those institutions. While Michigan and whittier have been coectucational for many years, Princeton began admitting female undergrachates anly in 1969. In 1986 about a third of Princeton's seniors were women, abourt 40 percent of Michigan's, and about half of Whittier's.

The methods for collecting the data differed amang the schools. Both Princeton and Whittier were unable to provide official documents with the number of faculty by gender, department, and year. Hence, we tabulated the data by hand using past editions of the relevant undergrachuate announcements. When finst names were androgynous, we 
consulted with various adninistrative officials to determine gender. The Michigan faculty data were compiled for us by the school's administration.

With respect to data on students, the Princeton and Michigan Registrar's Offices provided us tabulations from various public and internal records. The Princeton data consist of figures from the graduating class of 1973 through 1991. At Michigan, the contimuas set of student data begins with the graduating class of 1979 and extends through 1992. The Whittier student data were mare cauplicated to assemble. For the period 1980-88, the Registrar's Office tabulated the data. For years prior to 1980, no tabulated statistics were available, and the Registrar provided us with lists of the names and majors of the students who received their degrees each year from 1954 through $1979 .^{8}$ Unfortumately, in the mid-1970s, Whittier instituted scme new programs that encouraged students to take independent and interdisciplinary majors. These changes made it inpossible to conpare meaningfully the numbers of majors in various departments in the pre and post-1973 periods. We therefore focus on the 1974-88 period, which has the greatest overlap with the Princeton and Michigan data.9

Sumary statistios for the Prinoeton, Michigan, and Whittier data are presented in Tables 1a, $1 b$ and 1c, respectively. For each school, the left-hand side of the table shows the mean over the relevant sample period of the proportion of female faculty in each department, the standard deviation and the minimm and maximm values of the proportion. ${ }^{10}$ The right-hand side of the table exhibits the same information for graduating students. 
Casual inspection of the tables suggests several observations. First, female faculty are distributed across departments mare or less along the expected lines. At Princeton, for example, the man proportion of females in the chemistry department is only 0.009 , while in Romance Languages and Literature it is 0.240. Second, in many departments there appears to be a substantial anount of variation over time in the proportion of female faculty. In Michigan's chemical Engineering Department, for instance, the mean proportion is 0.015 , but it ranges fran 0.0 to 0.12 . This is important, because same intertemporal variation in the proportion of female faculty is needed if ane is to identify the impact of changing that proportion on the gender composition of the students.

Finally, within institutions there appears to be a positive corcelation between the proportion of female students in a department and the proportion of female faculty. To examine this phencmenon mace carefully, we used 1986 data to estimate for each institution a regression of the proportion of female majors in the gracuating class on the propartion of female faculty. In each case, the coefficient on the proportion of female faculty was positive and exceeded its standard error by more than a factor of four. ${ }^{11}$ These findings confirm the results in the sociology literature that female faculty and undergrachates tend to end up in the same departments. However, as stressed above, this correlation tells us nothing about whether undergrachates' choices of majors are influenced by the gender composition of the faculty. We now tron to the specification and estimation of a more appoporiate statistical model. 


\section{Statistical Model and Results}

In this section we specify and estimate orr basic model. We then estimate several variations of the model to assess the robustness of the results.

\subsection{Statistical Model}

Consider a group of students who graduate fram a school in year $t$. We define STUFEM it $_{\text {as }}$ the propontion of the graduates in department 1 at a given school who are ferale. (For the sake of simplicity, we suppress the school subscripts.) Next we define FACFPM the faculty in department $i$ at the time that students who graduated in year $t$ were choosing their majors. ${ }^{12}$ For our basic model, FACFEM 1 is computed as the average of the proportions of female faculty that graduating members encountered hrring their first and second years. ${ }^{13}$ For example, to determine FACFEM $_{1 t}$ for department i in 1989, we would take the average of the female faculty proportions in 1986 and 1987.14

For each school we assume that

$$
\operatorname{STUFEM}_{1 t}=B_{0}+B_{1} \text { FACFEM }_{1 t}+B_{2} t+B_{3} t^{2}+f_{1}+\epsilon_{1 t}
$$

where $t$ is a time trend, $f_{i}$ is a departmental fixed effect, $\epsilon_{i t}$ is a random error, and the B's are parameters to be estimated. ${ }^{15}$. The flxed effect refers to all unchanging attributes of a department that might affect the proportion of the students who are female, such as cultural norms which indicate that certain flelds are "masouline" or "feminine." In practice, acoounting for the fixed effect amounts to including a series of dichotamous variables $\mathrm{MAJ}_{1 t}$, where $\mathrm{MAJ}_{\text {it }}=1$ if the observation is for department 1 and zero otherwise. The quadratic time trend takes into 
acoount any possible overall trends that might affect female enrollments. ${ }^{16}$ For exarlple, during arr sample period the proportion of female undergraduates at princeton grew substantially. The presence of the time trend assures that we do not falsely attribute to the gender composition of the faculty any increases in female enrollments that were really due to the increased representation of women in the student body as a whole. A final estimation issue arises because the variances of the error terms may vary systematically across departments. Therefore, we camputed robust (Huber) standard errors for all the regression cofficients.

\subsection{Basic Results}

The parameter estimates for equation (1) using the Princeton, Michigan, and Whittier data sets are reported in Tables 2a, 2b, and 2c, respectively. Consider first the Princeton results. When interpreting the cofficients of the department variables, note that English is cmitted fram the regression, so the coefficient on each department shows its propartion of female majors relative to mglish, ceteris paribus. The coefficients on the department variables are generally statistically significant on a cre-by-one basis; indeed, an F-test easily rejects the rull hypothesis that the coeficients on the major variables are jointly zero. ${ }^{17}$ The time trend is also significant at conventional significance levels. Orr main foous, however, is the coefficient on FAcFEM It $_{\text {. The }}$ point estimate, 0.054 , is minute-it suggests that raising the percentage of female faculty in a department by 10 percentage points, ceteris paribus, would increase the percentage of female undergrachates by only 0.54 percentage points. In fact, given that the associated standard error 
is 0.106 , one cannot reject the hypothesis that the ocefficient is zero. Thus, the Princeton data do not support the view that the gender camposition of a department affects the gender camposition of its undergraduate majors.

The stories for Michigan (Table 2b) and Whittier (Table 2c) are

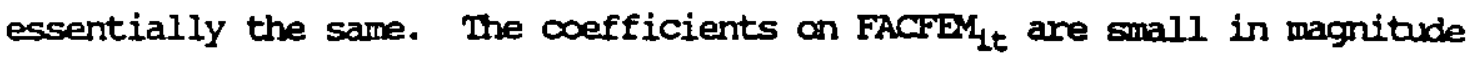
and statistically insignificant. As was true for Princeton, the major fixed effects are statistically significant. ${ }^{18}$ Unlike the Prinoeton case, the time trends are not statistically significant for Michigan and Whittier. However, when we estimated the equations without the trend, the results were substantially unchanged. That is, the coefficient on FACFEM $_{\text {it }}$ remained statistically insignificant, providing no support for the notion that the gender composition of a department's faculty affects the gender camposition of its undergraduate majors. 19

\subsection{Altermative Specifications}

our inability to reject the hypothesis that role model effects are absent might be due to same misspecification in equation (1). To assess the robustness of arr results, in this section we examine several alternative specifications.

Functional Form. Equation (1) assumes that the proportion of female undergraduates increases Iinearly with the proportion of female faculty, ceteris parjbus. Another possibility is that the presence of any female faculty in a department destroys the preconception that only men can suoceed in the field, and onoe any female faculty are present, adding additional women has no effect on female undergraduate enrollments. To examine this possibility, we created the dichotamous variable DFit, which 
equals one if there were any females in department $i$ at the time that graduates of year $t$ were choosing their majors and zero otherwise. Following the corvention used in defining FACFEM ft $_{\text {, this amounts to }}$ determining whether there were any women in the department curing the student's first or second years. For each school we then estimated

$$
\operatorname{STUFEM} M_{1 t}=B_{0}^{\prime}+B_{1}^{\prime} D F_{1 t}+B_{2}^{\prime} t+B_{3}^{\prime} t^{2}+f_{1}+\epsilon_{1 t} .
$$

Panel A of Table 3 reports the estimated coefficients on $D F_{1 t}$ and their standard errors; the other coefficients are not reported in order to conserve space. For no school can one reject the hypothesis that the coefficient on $D F_{\text {it }}$ is zero.

Another exercise in the same spirit is to determine whether the proportion of female undergraduate majors increases when the proportion of female faculty exoseds same critical value. This is the notion that a "critical mass" of female faculty in a department is needed to induce undergraduate women to enroll. To investigate this issue, we created the variable DF15t 1 , which equals one if the proportion of female faculty in department $i$ excoeded 15 percent in the relevant year, and zero otherwise. We then replaced $D F_{i t}$ in equation (2) with $D F 15 t_{i t}$, and re-estimated the equation. The results are reported in Panel A of Table 3. The coeficients for Princeton and Whittier continue to be statistically insignificant. The coefficient for Michigan is statistically significant, but its sign suggests that when a critical mass of female faculty is reached, the proportion of felmale majors decreases. ${ }^{20}$ we are not inclined to make much of this result-The coefficient is small in magnitude, and if one rums enough regressions, sooner or later a 
significant coefficient is bound to energe. Still, this finding certainly does not provide any support for the conventional view.

The models reported in Panel A embody a very extreme assumption on how additions to the mmber of female faculty might affect female enrollments-after sane number of fenale faculty members is reached, the incremental impact of any others is zero. A less extreme type of diminishing marginal returns can be modelled by including a quadratic in FACFEM it :

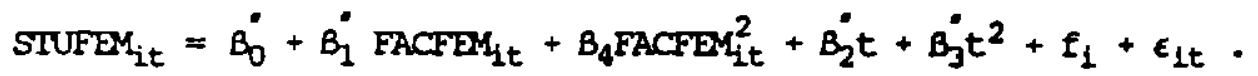

The coefficients on the linear and quadratic terms are reported in Panel $B$ of Table 3; again, the other coefficients are suppressed. For each school the linear and quadratic terms are indivicually and jointly insignificant. ${ }^{21}$ Hence, allowing for nonlinear effects does not change the basic result.

Department size. Male and female undergraduates may differ in their tastes with respect to department size. While it is hard to predict just what these differenoes might be (do wanen prefer the anorymity of a large department or the cory atmosphere of a small department?), it seens worthwhile to determine whether department size exercises an independent effect on wamen's choice of majors, and whether its cmission from equation (1) biases the coefficient on FACFBM ${ }_{1 t}$. Hence, we augmented equation (1) with the variable SIZE $E_{1 t}$, the number of students (female plus male) in department $i$ when the graduates of year $t$ were selecting their majors. ${ }^{22}$ Panel $C$ of Table 3 exhibits the resulting coefficients on FACFEM $1 t$ and $\operatorname{SIZE}_{i t}$. They suggest that departwent size does not exert an independent 
effect on the propensity of females to major in a department, and this variable's inclusion does not substantially affect the coefficient on FACFEM

Laq structure. We have assumed that a woman's selection of her major is based equally on the gender camposition of the faculty in her first and second years as a student. However, changes in the propartion of female faculty might affect stadents' decisions with same other lag. To investigate the possibility that arr results are sensitive to the lag structure, we defined FACFEM ${ }_{i t}$ as the proportion of female faculty in department $i$ when the graduating seniors of year $t$ were first-year students and FACFEM ${ }_{1 t}$ analogously. We then re-estimated equation (1) replacing FACFEM ${ }_{1 t}$ with: a) FACFEMI $_{1 t}$, b) FACFEM ${ }_{1 t}$ and c) both FACFEM ${ }_{1 t}$ and FACFEM ${ }_{i t}$. Specification a) assumes that the first year is formative; b) assumes it is the second year; and c) permits both years to matter, but does not constrain the effects to be the same. The results are reported in Panel $D$ of Table 3 . The coefficients remain statistically insignificant. Hence, the absence of gender effects does not appear to be due to a misspecification of the lag structure.

Tenure status. Our model treats all faculty members the same, regardless of their rank. However, to the extent that terurred faculty have more prestige and visibility than their non-termed counterparts, then it might be more appropriate to focus on the proportion of female faculty in the terured ranks only. We therefore created the variable TENFEM $_{i t}$, the analogue to FACFEM ${ }_{i t}$ for the temured faculty. We were able to construct TENFEM 1 for Princeton and Michigan only; the results are in Panel $E$ of Table 3. They are not very different from their FAcFEM 
counterparts in Tables $2 a$ and $2 b$. Of course, one could just as well argue that non-terured faculty are more relevant role models, because they are relatively young and may be more heavily involved in undergraduate instructional programs. However, when the female proportion of nonterurred faculty members is used as a right-hand-side variable, its coeficient is also statistically insignificant. We conclude that taking into acoount differences in faculty rank does not change arr results. Sciences vs, humanities and social sciences. The policy discassion that surrounds our issue has fooused on the desire to increase female representation in the scienoes. However, arr basic specification pools the sciences and non-sciences together, operating on what we take to be the reasorable view that to the extent the notion of gender role models is relevart, it applies symmetrically to the sciences and non-sciences. Nevertheless, it is possible that the processes governing entry into different types of departments differ, and that by pooling then together, we are obscuring the impact of faculty gender composition. Hence, we reestimated equation (1) using just the science departments, and then repeated the process just for the humanities and social sciences. ${ }^{23}$ Panel $F$ of Table 3 shows the ooefficients on FAcrEY It $_{\text {far }}$ the science and non-science departments. The coefficients fram both regressions are statistically insignificant. The gender composition of the faculty has no mare impartance in science departments than in the others.

pooling the institutions. So far, we have estimated each model separately by institution. Perhaps if all three data sets were used together it would be possible to abtain more precise estimates. We therefore created a model suitable for analyzing all three data sets 
simultaneously. The model is a variant of equation (1) in which $B_{0}, B_{2}$, $B_{3}$ and the department fixed effects are allowed to vary by institution, but the coefficients on FACrEM $_{1 t}$ are constrained to be the same. Mechanically, this involved creating a dichotamous variable for each institution, and interacting it with each of the right-hand side variables except FACFEM ${ }_{i t} \cdot{ }^{24}$ Estimation of this model with the pooled data set yielded a coefficient on FACFEM $_{\text {it }}$ of 0.0714 with a stardard error of 0.0888 . Thus, pooling the data does not change our by now, familiar finding-the gender composition of a department's faculty exerts no statistically discernible effect on the gender composition of its undergrachute majors.

\section{Conclusion}

It is frequently asserted that female undergraduate enroliments in the sciences and engineering could be increased by raising female representation on the faculties in these areas. We have assembled panel data fram three rather different educational institurions and used them to examise this proposition. The econometric analysis indicates that one cannot reject the hypothesis that the gender composition of the students in an academic department is unaffected by the gender camposition of the faculty at the time the students select their majors. This finding holds for each institution, and is rabust with respect to a muber of reasconable alternative specifications of the statistical model.

of course, this analysis hardly exhausts the possibilities for empirical work on this topic. The most abvious averue for future research would be the collection and analysis of data fram additional schools. An even more ambitious research agenda would involve the collection of micro 
data on individual students and the genders of their instructors. This would allow researchers to investigate whether role model effects are present for some types of students and not others. Such effects are diffialt to discern in a study like ours, which relies on data at the department level. Things are further complicated by the fact that increasing female faculty in certain disciplines might have long-term and inirect effects by influencing social definitions of appropriate majors for men and women. Having made these points, however, we believe that our research shifts the burden of proof to those who assert that hiring female faculty in a department is an efficacious way to increase its undergraduate female enrollments.

Do our results say arything more general about the validity of the notion that females need role models to enoourage them to enter certain majors? The answer is clearly no. It oould be, for example, that young wrmen's decisions are driven by the presence or absence of female role models, but these role models appear in their lives before entering college. High school teachers, family members, and public figures come to mind here. Further, even if female role models don't affect choice of major, they may affect post-oollege artoomes; such as the propensity of women in the department to go on to graduate school. (See Rothstein [1994].) Of course, we must also contemplate the possibility that a person can be inspired by scmeone of another gender. One may want to follow the lead of a person who is similar in race, ethnicity, religion, social background, etc. Or pertaps role models don't matter very much at all-individuals choose careers solely on the basis of their capabilities and the constraints they face, the traditional view in economics, as 
reflected in Ehrenberg's [1992] survey. Orr research says nothing abourt these more general issues. It does, however, suggest that mamy hypotheses in this area can and should be subjected to enpirical testing. 


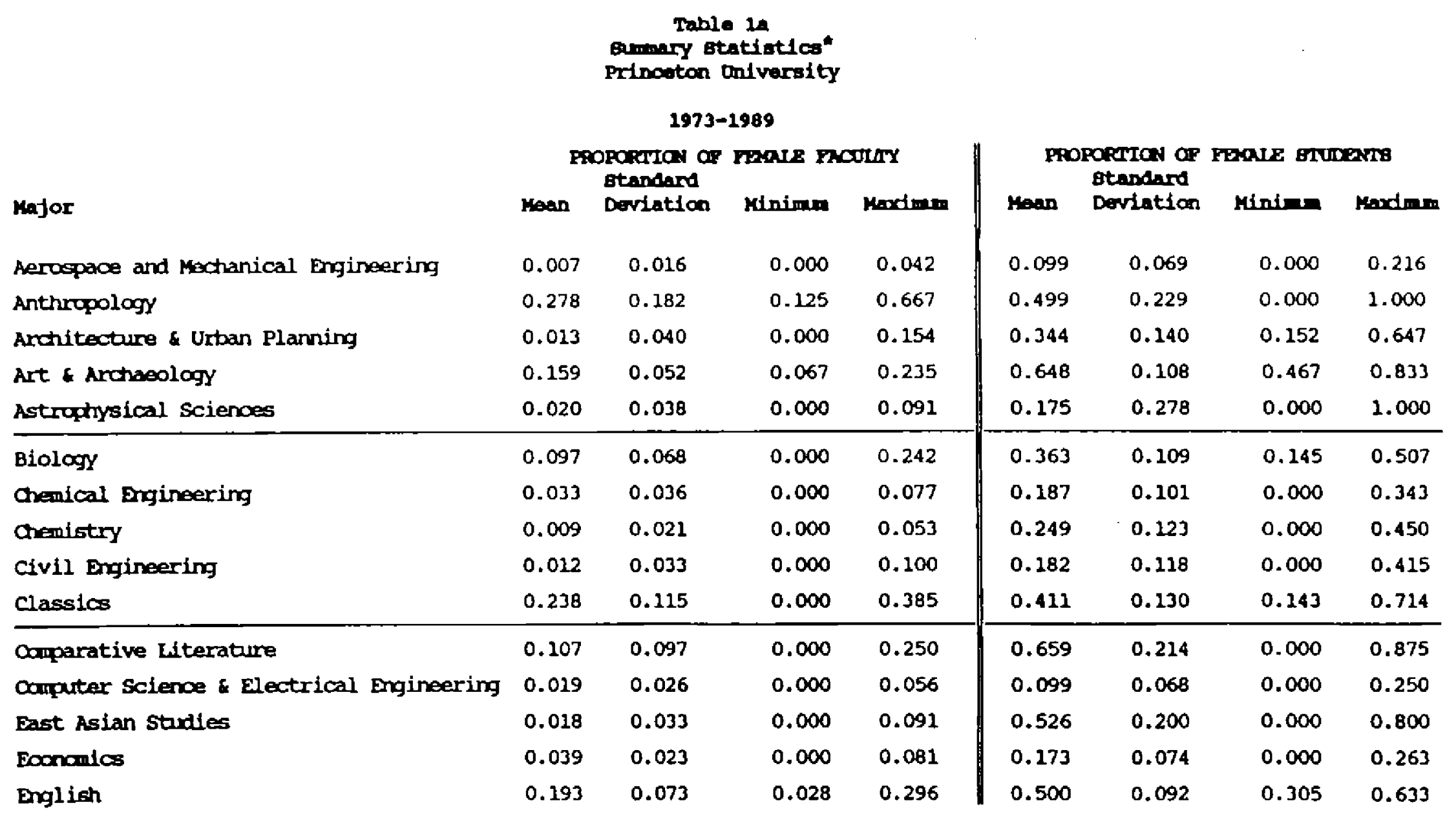


Table is (continued)

Major

Geology

Cermanic Languages and Literature

History

Mathematics

Music

Near Eastern Studies

Philosophy

Physics

Politics

Psychology

Religion

Ramance Languages \&iterature

Slavic Languages and Literature

Sociology

Statistics

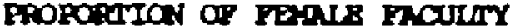

Btandind Hav Devlation Mintmo Modmm

$\begin{array}{llll}0.056 & 0.068 & 0.000 & 0.200\end{array}$

$0.176 \quad 0.084$

$0.121 \quad 0.046$

$0.007 \quad 0.016$

0.073

0.0330 .043

0.073

0.011

0.086

0.143

0.141

0.240

0.291

0.144

0.000
0.089

0.041

0.012

0.030

0.073

0.161

0.101

0.131

0.046

0.000
0.000

0.047

0.000

0.000

0.000

0.000

0.048

0.000

0.033

0.000

0.000

0.105

0.000

0.056

0.000

0.200

0.300

0.226

0.047

0.200

0.133

0.111

0.026

0.136

0.261

0.364

0.433

0.400

0.214

0.000

\section{proporitas of FenIe BTUDents}

Btandard Hasn Deviation Miniman Moximm

$\begin{array}{llll}0.406 & 0.237 & 0.000 & 1.000\end{array}$

0.484

0.288

0.000

1.000

0.335

0.121

0.078

0.175

0.462 0.277

0.094

0.000

0.286

$\begin{array}{llll}0.424 & 0.181 & 0.000 & 0.786\end{array}$

0.209

0.121

0.000

0.450

0.093

0.062

0.000

0.200

0.291

0.100

0.123

0.441

0.431

0.103

0.222

0.643

0.430

0.178

0.000

0.690

0.725

0.156

0.333

0.941

0.719

0.194

0.400

1.000

0.567

0.180

0.136

0.769

0.415

0.321

0.000

1.000

scarce: Faculty data are from various editions of The Prinoeton University Undercraduate Announcinent. Student data for the years 1973-1981 and 1982-1985 are from: Department of Health, biucation and Helfare, Educational Division, Hicher Education General. Information survey (Washington, D.C.: Covernment Printing office) - For 1981-82 they are from: Princeton University office of the Registrar, Bachelor's, Master's and Doctor's Degrees Conferned (horking Paper). For 1985-1991 they are from U.S. Department of Camerce, Bureau of the Census Acting as Collection Agent for U.S.

Department of Education, National Center for Education statistics Interrated post-secondary Education Data system: completions Survey (Washington, D.C.: Goverment Printing office). 


\section{Mafor}

Aerospace Engineering

Anthropology

Art \& Archaeology

Astranany

Atmospheric and oceanic Sclence

Biology

Biology

Chemical Engineering

onemistry

Civil \& Envirormental Engineering

classics

Omminication

past Asian Studies

Boononics

Electrical Engineering 6 camputer science

English

Geology

Cermanic Langrages \& Literature

History

Industrial \& Operations Engineering

Linguistics
Table ib

ammary Btatiotica"

Univaralty of xichigan

1979-1990

proporutos of Feate Factury Btandard

maan Deviation

0.028

0.021

0.212

0.065

0.304

0.067

0.000

0.000

0.000

0.098

0.011

0.015

0.037

0.038

0.014

0.062

0.028

0.193

0.062

0.192

0.098

0.198

0.055

0.078

0.020

0.016

0.143

0.285

0.008

0.020

0.215

0.042

0.111

0.045

0.041

0.040

0.309

0.101

TY

intmen raximen

0.000

0.067

0.214

0.000

0.000

0.085

0.000

0.026

0.038

0.067

0.063

0.211

0.029

0.017

0.000

0.133

0.061

0.000

0.154

0.046

0.316

0.455

0.000

0.000

0.116

0.118

0.059

0.120

0.364

0.400

0.086

0.068

0.211

0.053

0.294

0.196

0.105

0.500
Propoftrion of frate GTUDENIs Btandard moan Deviation Minimas Maximm

$\begin{array}{llll}0.112 & 0.034 & 0.067 & 0.166\end{array}$

$\begin{array}{lllll}0.587 & 0.080 & 0.450 & 0.679\end{array}$

$\begin{array}{llll}0.805 & 0.063 & 0.667 & 0.889\end{array}$

$\begin{array}{lllll}0.047 & 0.088 & 0.000 & 0.250\end{array}$

$\begin{array}{lllll}0.280 & 0.139 & 0.067 & 0.563\end{array}$

$\begin{array}{lllll}0.402 & 0.046 & 0.315 & 0.484\end{array}$

$\begin{array}{llll}0.250 & 0.057 & 0.196 & 0.349\end{array}$

$\begin{array}{llll}0.267 & 0.070 & 0.161 & 0.395\end{array}$

$\begin{array}{llll}0.278 & 0.132 & 0.132 & 0.640\end{array}$

$\begin{array}{llll}0.569 & 0.201 & 0.250 & 1.000\end{array}$

$\begin{array}{llll}0.673 & 0.054 & 0.596 & 0.769\end{array}$

$\begin{array}{llll}0.490 & 0.108 & 0.273 & 0.660\end{array}$

$\begin{array}{llll}0.335 & 0.042 & 0.267 & 0.397\end{array}$

$\begin{array}{llll}0.155 & 0.026 & 0.111 & 0.192\end{array}$

\begin{tabular}{cccc}
0.601 & 0.042 & 0.527 & 0.652 \\
\hline 0.428 & 0.177 & 0.125 & 0.611
\end{tabular}

$\begin{array}{lllll}0.348 & 0.068 & 0.189 & 0.412\end{array}$

$\begin{array}{llll}0.706 & 0.139 & 0.444 & 0.909\end{array}$


Table ib (Continued)

natar

Materials Scienoe Engineering

Mecthanical Exgineering

Naval \& Marine Enginearing

Near Eastern stadies

Nuclear Dingineering

Fillosaphy

Ahysics

Political science

Paychology

Romance Languages \& Literature

Slavic Languages \& Literature

soctology

statistios
Mathematics
Frororitas of FenIs pactury

Btandard

man Deviation Mintma Modman

$0.000 \quad 0.000$

0.031

0.029

0.000

0.068

0.038

0.066

0.002

0.130

0.204

0.214

0.148

0.155

0.014
0.000
0.013

0.026

0.000

0.020

0.040

0.038

0.005

0.047

0.055

0.029

0.043

0.069

0.048
0.000

0.016

0.000

0.000

0.056

0.000

0.000

0.000

0.000

0.067

0.152

0.152

0.160

0.091

0.053

0.000
ఉSauroe: Faculty d

were tabulated by the Staff and Faculty Records division of the University of Michigan. Student count by Sud cant by sudent Level. For 1985-1992, they are from University of Michigan at Ann Arbor office of the Registrar, Undercraduate Students by Unit, Field of Specialization. Upper Division class Level. and sex.

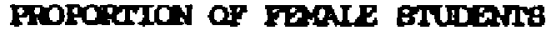
Btandand

Deriation Mindmin Madmin

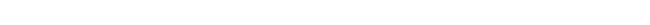

$\begin{array}{llll}0.268 & 0.094 & 0.167 & 0.409\end{array}$

$\begin{array}{llll}0.416 & 0.105 & 0.268 & 0.622\end{array}$

$\begin{array}{llll}0.141 & 0.028 & 0.075 & 0.178\end{array}$

$\begin{array}{llll}0.044 & 0.051 & 0.000 & 0.154\end{array}$

\begin{tabular}{llll}
0.449 & 0.252 & 0.000 & 1.000 \\
\hline 0.108 & 0.076 & 0.000 & 0.250
\end{tabular}

$0.000-0.250$

$\begin{array}{llll}0.321 & 0.115 & 0.100 & 0.529\end{array}$

$\begin{array}{llll}0.101 & 0.041 & 0.047 & 0.184\end{array}$

$\begin{array}{llll}0.421 & 0.036 & 0.346 & 0.469\end{array}$

$\begin{array}{llll}0.689 & 0.025 & 0.642 & 0.727\end{array}$

$\begin{array}{lllll}0.269 & 0.791 & 0.079 & 0.613 & 0.920\end{array}$

\begin{tabular}{l|llll}
0.200 & 0.476 & 0.087 & 0.286 & $0.57 \chi$
\end{tabular}

\begin{tabular}{l|llll}
0.286 & 0.705 & 0.054 & 0.627 & 0.800
\end{tabular}

$\begin{array}{lllll}0.167 & 0.372 & 0.188 & 0.000 & 0.600\end{array}$ 
2able 10

Qminary Btatiotios

whittiar oolloge

1974-1986

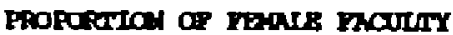

Najor

Btandard

Art

Maan Dortation

Art

Biology

Business Administration

Chemistry

Englesh

foreign Iampuages o Litaratire

coology

History

Home Economics

Mathematics

Music

Fillosophy

Fysical puration

Physics

Doviation

Minime Madrese

polltical scierce

$0.126 \quad 0.247$

$0.246 \quad 0.166$

$0.032 \quad 0.062$

$0.062 \quad 0.096$

0.435

0.449

0.094

0.000

0.667

0.000

0.400

Pyctology

Peligion

sociology

speech

0.449
0.167

\subsection{0}

1.000

0.071

0.284

0.226

0.000

\subsection{0}

0.167

$0.000 \quad 0.200$

0.250

$0.000 \quad 1.000$

$0.000 \quad 0.500$

$\begin{array}{ll}0.000 & 0.500 \\ 0.000 & 0.000\end{array}$

1.000

0.000
1.000

0.386

0.235

0.000

0.333

0.250

0.075 .

0.237

0.000

0.000

$0.000 \quad 0.000$

0.000

0.183

0.000

0.500

$\begin{array}{ll}0.097 & 0.099\end{array}$

0.000

$0.353 \quad 0.159$

0.000

0.286

$0.000 \quad 0.000$

0.000

0.750

0.397

0.177

0.250

0.000

0.046

0.088

0.000

0.200

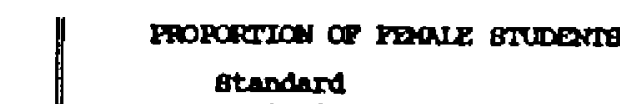

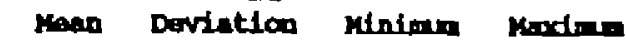

$\begin{array}{llll}0.655 & 0.358 & 0.000 & 1.000\end{array}$

$\begin{array}{llll}0.400 & 0.112 & 0.211 & 0.565\end{array}$

"Faculty data are from various editions of The Hittfer collene undergrequate announceinent. stadent data for years prior to 1980 were frum lists provided by the whittier college administration. After 2980, they are frum the Department of Health, Education and Welfare, Etucational Division, Higher Education Ceneral

Information Suryey (Washington, D.C.: Coverment Printing office). 
Table $2 a$

Estimates of Equation (1) for Prinoston"

\begin{tabular}{|c|c|c|c|}
\hline Variable & & & \\
\hline FACFPM $_{\text {it }}$ & $\begin{array}{r}0.0542 \\
(0.109)\end{array}$ & Eoanamics & $\begin{array}{l}-0.333 \\
(0.0216)\end{array}$ \\
\hline$t$ & $\begin{array}{l}0.0280 \\
(0.00505)\end{array}$ & Geology & $\begin{array}{l}-0.0945 \\
(0.0509)\end{array}$ \\
\hline$t^{2}$ & $\begin{array}{l}-0.000998 \\
(0.000227)\end{array}$ & German & $\begin{array}{r}-0.0215 \\
(0.0644)\end{array}$ \\
\hline Aercospace Exgineering & $\begin{array}{l}-0.390 \\
(0.0248)\end{array}$ & History & $\begin{array}{l}-0.168 \\
(0.0154)\end{array}$ \\
\hline Anthropology & $\begin{array}{l}-0.00684 \\
(0.0501)\end{array}$ & Mathematics & $\begin{array}{l}-0.373 \\
(0.0307)\end{array}$ \\
\hline Architecture & $\begin{array}{l}-0.144 \\
(0.0315)\end{array}$ & Music & $\begin{array}{l}-0.223 \\
(0.0467)\end{array}$ \\
\hline Art \& Archaeology & $\begin{array}{l}0.155 \\
(0.0290)\end{array}$ & Near Eastern Studies & $\begin{array}{l}-0.0819 \\
(0.0428)\end{array}$ \\
\hline Astraphysics & $\begin{array}{l}-0.327 \\
(0.0699)\end{array}$ & Fhلllosoghy & $\begin{array}{l}-0.285 \\
(0.0295)\end{array}$ \\
\hline Biology & $\begin{array}{l}-0.129 \\
(0.0201)\end{array}$ & Frysios & $\begin{array}{l}-0.393 \\
(0.0251)\end{array}$ \\
\hline Cxemical Exgineering & $\begin{array}{l}-0.302 \\
(0.0253)\end{array}$ & Politics & $\begin{array}{l}-0.210 \\
(0.0214)\end{array}$ \\
\hline chenistry & $\begin{array}{l}-0.237 \\
(0.0280)\end{array}$ & Psychology & $\begin{array}{l}-0.0656 \\
(0.0204)\end{array}$ \\
\hline Civil Exineering & $\begin{array}{l}-0.307 \\
(0.0265)\end{array}$ & Religion & $\begin{array}{c}-0.0755 \\
(0.0309)\end{array}$ \\
\hline Classics & $\begin{array}{l}-0.102 \\
(0.0299)\end{array}$ & $\begin{array}{l}\text { Ramance Languages } \\
\text { \& Literature }\end{array}$ & $\begin{array}{l}0.217 \\
(0.0307)\end{array}$ \\
\hline Comparative Iiterature & $\begin{array}{l}0.142 \\
(0.0468)\end{array}$ & $\begin{array}{l}\text { Slavic Ianguages } \\
\text { Literature }\end{array}$ & $\begin{array}{l}0.189 \\
(0.0481)\end{array}$ \\
\hline $\begin{array}{l}\text { Camputer Science \& } \\
\text { Electrical Engineering }\end{array}$ & $\begin{array}{l}-0.400 \\
(0.0217)\end{array}$ & sociology & $\begin{array}{r}0.0699 \\
(0.0325)\end{array}$ \\
\hline
\end{tabular}


Table 22 (cortinued)

Variable

East Asian Stadies

$N$

$R^{2}$

$$
0.0368
$$

$(0.0468)$

Statistics

Canstant
$-0.0615$

(0.0952)

0.349

$(0.0253)$

- The deperdert variable is the proportion of female majors in department 1 in year $t$ and FACFay, is the proportion of female faculty in department 1 that graduates of year $t$ confruted wen they were selecting thelr majors. Florures in parentheses are standard errors, which are corrected for heteroskedasticity using huber's method. The conitted department major is English. 
Table ab

Retimates of Eguation (1) for xichtgan

\begin{tabular}{|c|c|c|c|}
\hline \multicolumn{2}{|l|}{ Variable } & \multicolumn{2}{|l|}{-} \\
\hline FACFEM $_{i t}$ & $\begin{array}{l}-0.248 \\
(0.138)\end{array}$ & History & $\begin{array}{l}-0.225 \\
(0.0176)\end{array}$ \\
\hline$t$ & $\begin{array}{l}0.0104 \\
(0.00494)\end{array}$ & $\begin{array}{l}\text { Inchustrial \& } \\
\text { Operations Engineering }\end{array}$ & $\begin{array}{l}-0.274 \\
(0.0220)\end{array}$ \\
\hline$t^{2}$ & $\begin{array}{l}-0.000428 \\
(0.000306)\end{array}$ & Linguistios & $\begin{array}{l}0.163 \\
(0.0447)\end{array}$ \\
\hline Aerospace Engineering & $\begin{array}{l}-0.505 \\
(0.0185)\end{array}$ & $\begin{array}{l}\text { Materials Science } \\
\text { Engineering }\end{array}$ & $\begin{array}{l}-0.373 \\
(0.0309)\end{array}$ \\
\hline Arthropology & $\begin{array}{l}0.00514 \\
(0.0214)\end{array}$ & Mathematics & $\begin{array}{l}-0.213 \\
(0.0311)\end{array}$ \\
\hline Art \& Archaeology & $\begin{array}{l}0.254 \\
(0.0272)\end{array}$ & Mechanical Engineering & $\begin{array}{l}-0.477 \\
(0.0184)\end{array}$ \\
\hline Astranamy & $\begin{array}{l}-0.574 \\
(0.0316)\end{array}$ & $\begin{array}{l}\text { Naval and Marine } \\
\text { Engineering }\end{array}$ & $\begin{array}{l}-0.583 \\
(0.0251)\end{array}$ \\
\hline $\begin{array}{l}\text { Atmospheric \& } \\
\text { Dceanic Science }\end{array}$ & $\begin{array}{l}-0.342 \\
(0.0408)\end{array}$ & Near Eastern Studies & $\begin{array}{l}-0.183 \\
(0.0624)\end{array}$ \\
\hline Biolœgy & $\begin{array}{l}-0.196 \\
(0.0138)\end{array}$ & Nuclear Engineering & $\begin{array}{l}-0.532 \\
(0.0259)\end{array}$ \\
\hline Chemical Engineering & $\begin{array}{l}-0.370 \\
(0.0235)\end{array}$ & Fhtlosoghy & $\begin{array}{l}-0.295 \\
(0.0315)\end{array}$ \\
\hline Chemistry & $\begin{array}{l}-0.331 \\
(0.0233)\end{array}$ & Plnysios & $\begin{array}{l}-0.518 \\
(0.0242)\end{array}$ \\
\hline $\begin{array}{l}\text { Civil \& Envirumental } \\
\text { Engineering }\end{array}$ & $\begin{array}{l}-0.344 \\
(0.0356)\end{array}$ & Political sclence & $\begin{array}{l}-0.182 \\
(0.0127)\end{array}$ \\
\hline Classics & $\begin{array}{l}-0.0454 \\
(0.0564)\end{array}$ & Psyctology & $\begin{array}{l}0.105 \\
(0.0132)\end{array}$ \\
\hline Omminiation & $\begin{array}{c}0.0713 \\
(0.0163)\end{array}$ & $\begin{array}{l}\text { Romance Languages \& } \\
\text { Literature }\end{array}$ & $\begin{array}{l}0.202 \\
(0.0246)\end{array}$ \\
\hline East Asi & $\begin{array}{l}-0.0757 \\
(0.0311)\end{array}$ & $\begin{array}{l}\text { Slavic Languages and } \\
\text { Literatume }\end{array}$ & $\begin{array}{l}-0.109 \\
(0.0231)\end{array}$ \\
\hline
\end{tabular}


Table 2b (contirued)

\begin{tabular}{lccc} 
Variable & & \\
\cline { 3 - 3 } Econamics & -0.291 & Sociology & 0.107 \\
& $(0.0185)$ & & $(0.0165)$ \\
Electrical Engineering & -0.472 & Speech & -0.226 \\
\& Computer Science & $(0.0184)$ & & $(0.0523)$ \\
Geology & -0.209 & Constant & 0.585 \\
& $(0.0491)$ & & $(0.0229)$ \\
German & 0.0316 & & \\
& $(0.0255)$ & & \\
$N$ & & & \\
$R^{2}$ & & &
\end{tabular}

* See note to Table $2 a$. 
Table 20

Estimates of Equation (1) for multtier*

\section{Variable}

FAcrim,

0.123

$(0.133)$

$t$

$$
0.0147
$$

$(0.0464)$

$t^{2}$

$-0.000156$

$(0.000843)$

Art

$$
\begin{aligned}
& 0.00508 \\
& (0.101)
\end{aligned}
$$

Biology

$-0.292$

(0.0538)

Qusiness

$-0.325$

$(0.0685)$

Chenistry

$-0.307$

$(0.0805)$

Foreign Language

0.197

$(0.0673)$

ceology

$-0.379$

$(0.113)$

Histary

$-0.193$

$(0.0889)$

Hane Ecanamics

0.194

$(0.0972)$

Mathematios

$-0.192$

$(0.0876)$

Msic

$-0.0497$

$(0.104)$

Frilosophy

0.0862

$(0.168)$ $\begin{array}{ll}\text { Physical Education } & -0.339 \\ & (0.0549)\end{array}$

Prysics

$-0.638$

$(0.0693)$

political science $\quad-0.320$

$(0.0648)$

Psyctology

$-0.00790$

$(0.0568)$

Religion

$-0.223$

(0.191)

Sociology

0.0230

$(0.0658)$

Speech

0.143

$(0.0680)$

constant

0.352

$(0.626)$

$\mathbf{N}$

251

$R^{2}$

0.54

- See note to Table $2 a$. 
Table 3

\section{Ilternative epecifications*}

A. Dichotanous Variables for Female Faculty

$$
\text { Princeton Michigan whittier }
$$

$\begin{array}{lccc}\mathrm{DF}_{\mathrm{it}} & -0.0103 & 0.00147 & 0.0322 \\ & (0.0167) & (0.0231) & (0.0465) \\ \mathrm{DF} 15 \mathrm{f}_{\mathrm{it}} & 0.0349 & -0.0483 & 0.0505 \\ & (0.0222) & (0.0183) & (0.0451)\end{array}$

B. Quadratic in the Proportion of Female Faculty

$\begin{array}{cccc} & \text { Princeton } & \text { Michigan } & \text { Whittier } \\ \text { FACFEM, } & 0.258 & -0.609 & 0.217 \\ & (0.199) & (0.336) & (0.298) \\ \text { FACFBYIt } & 0.0349 & -0.0483 & 0.0505 \\ & (0.0222) & (0.0183) & (0.0451)\end{array}$

C. Inclusion of Size of Undergrachute Enrollment Princeton Michigan Wittier

$\begin{array}{lccc}\text { FACFEY, }_{\text {t }} & 0.0554 & -0.252 & 0.215 \\ & (0.109) & (0.139) & (0.134) \\ \text { SIZE }_{\text {it }} \times 100 & 0.0316 & 0.00621 & -0.0708 \\ & (0.0427) & (0.00807) & (0.150)\end{array}$

D. Alternative Iags of Proportion of Fenale Faculty Prinoetan Michigan whittier

\begin{tabular}{|c|c|c|c|}
\hline $\begin{array}{l}\text { FACFEMA }_{i t} \\
-----\end{array}$ & $\begin{array}{c}0.0273 \\
(0.0971)\end{array}$ & $\begin{array}{r}-0.154 \\
-(0.117)\end{array}$ & $\begin{array}{c}0.172 \\
\ldots(0.124) \ldots \ldots\end{array}$ \\
\hline $\begin{array}{l}\text { FACFER is } \\
-----\end{array}$ & $\begin{array}{r}0.0634 \\
(0.1261\end{array}$ & $\begin{array}{r}-0.205 \\
-(0.111) .\end{array}$ & $\begin{array}{l}-0.00166 \\
-(0.104) \ldots \ldots\end{array}$ \\
\hline${ }^{2 A C F D C}{ }_{\text {is }}$ & $\begin{array}{l}-0.0309 \\
(0.196)\end{array}$ & $\begin{array}{l}-0.0778 \\
(0.120)\end{array}$ & $\begin{array}{l}-0.117 \\
(0.0933)\end{array}$ \\
\hline FACFER ${ }_{\text {it }}$ & $\begin{array}{c}0.0847 \\
(0.227)\end{array}$ & $\begin{array}{l}-0.170 \\
(0.115)\end{array}$ & $\begin{array}{c}0.242 \\
(0.130)\end{array}$ \\
\hline
\end{tabular}


E. Tenured Faally

Prinotan Michigan Whittier

TENray,

0.0691

$(0.200)$

$-0.168$

$(0.186)$

-

F. Sciences vs. Humanities and Social Sciences

a. Sciences

Princetan Michigan Whittier

$\begin{array}{cccc}\text { FACFEM }_{4 t} & 0.0636 & -0.674 & 0.120 \\ & (0.286) & (0.549) & (0.223)\end{array}$

b. Social sciences

and Hunaities

$\begin{array}{cccc}\text { FACFEM }_{4 t} & 0.0773 & -0.0812 & 0.105 \\ & (0.120) & (0.137) & (0.169)\end{array}$

- Each coefficlent is from a regression in which the dependert variable is the proportion of female majors in department $i$ in year $t$, and that on the right-hand side also includes a constant, major fiued effects, and a quadratic time trend. Figures in parentheses are standard errors, conrected for heteroskedasticity using Wite's method. $D F_{f t}=1$ if there were any female faculty in department i at the time that graculates of year $t$ were choosing their majors, and zero otherwise. DF158, 1 if the proportion of female faculty in department 1 at the time that gradutes in year $t$ were choosing their majors exceeded 15 percent, and zero otherwise. FAcriy, is the proporticn of female faculty in department 1 at the time that gramutes of year $t$ were selecting their majors. SIzE, is the rumber of students in departmert 1 in year $t$. Facreng is the proportion of female faculty in departient 1 when grachates of year $t$ were flrst-year sturdents, and FACFEv, is defined analogously for the year when they were second-year students. TENFry, is the analogue to FAcFay, for terured faculty only. 


\begin{tabular}{|c|c|c|c|c|}
\hline Major & Faculty & Faculty & Majors & Majora \\
\hline $\begin{array}{l}\text { Aerospace and } \\
\text { Mectanical Engineering }\end{array}$ & $\begin{array}{c}0.176 \\
(0.392)\end{array}$ & $\begin{array}{l}23.9 \\
(3.33)\end{array}$ & $\begin{array}{l}3.94 \\
(3.25)\end{array}$ & $\begin{array}{l}35.5 \\
(11.2)\end{array}$ \\
\hline Anthropology & $\begin{array}{l}1.88 \\
(1.22)\end{array}$ & $\begin{array}{l}6.76 \\
(0.970)\end{array}$ & $\begin{array}{l}3.76 \\
(2.54)\end{array}$ & $\begin{array}{c}7.47 \\
(3.86)\end{array}$ \\
\hline $\begin{array}{l}\text { Architecture \& Urtian } \\
\text { Planring }\end{array}$ & $\begin{array}{c}0.176 \\
(0.529)\end{array}$ & $\begin{array}{l}11.1 \\
(1.78)\end{array}$ & $\begin{array}{c}9.53 \\
(3.74)\end{array}$ & $\begin{array}{l}28.4 \\
(5.49)\end{array}$ \\
\hline Art \& Archaeology & $\begin{array}{l}2.65 \\
(0.996)\end{array}$ & $\begin{array}{l}16.3 \\
(1.99)\end{array}$ & $\begin{array}{l}15.5 \\
(4.14)\end{array}$ & $\begin{array}{l}23.7 \\
(4.70)\end{array}$ \\
\hline Astrophysical sciences & $\begin{array}{c}0.235 \\
(0.437)\end{array}$ & $\begin{array}{l}11.0 \\
(0.707)\end{array}$ & $\begin{array}{c}0.412 \\
(0.618)\end{array}$ & $\begin{array}{l}2.18 \\
(1.81)\end{array}$ \\
\hline Biology & $\begin{array}{l}3.06 \\
(2.28)\end{array}$ & $\begin{array}{l}30.9 \\
(4.15)\end{array}$ & $\begin{array}{l}31.7 \\
(10.9)\end{array}$ & $\begin{array}{l}86.8 \\
(13.0)\end{array}$ \\
\hline Chemical Engineering & $\begin{array}{c}0.471 \\
(0.514)\end{array}$ & $\begin{array}{l}14.4 \\
(0.939)\end{array}$ & $\begin{array}{l}6.0 \\
(4.76)\end{array}$ & $\begin{array}{l}29.8 \\
(13.6)\end{array}$ \\
\hline chemistry & $\begin{array}{l}1.176 \\
(0.393)\end{array}$ & $\begin{array}{l}18.6 \\
(2.21)\end{array}$ & $\begin{array}{c}5.65 \\
(3.26)\end{array}$ & $\begin{array}{l}22.1 \\
(7.52)\end{array}$ \\
\hline Civil Engineering & $\begin{array}{l}0.235 \\
(0.664)\end{array}$ & $\begin{array}{l}21.1 \\
(3.12)\end{array}$ & $\begin{array}{l}10.3 \\
(6.94)\end{array}$ & $\begin{array}{c}52.7 \\
(16.3)\end{array}$ \\
\hline Classios & $\begin{array}{l}3.12 \\
(1.62)\end{array}$ & $\begin{array}{l}12.7 \\
(1.53)\end{array}$ & $\begin{array}{c}4.47 \\
(1.66)\end{array}$ & $\begin{array}{l}10.9 \\
(3.29)\end{array}$ \\
\hline Coparative Literature & $\begin{array}{l}1.76 \\
(1.86)\end{array}$ & $\begin{array}{l}13.5 \\
(5.46)\end{array}$ & $\begin{array}{l}13.9 \\
(5.31)\end{array}$ & $\begin{array}{l}20.0 \\
(7.01)\end{array}$ \\
\hline $\begin{array}{l}\text { Camputer Science \& } \\
\text { Electrical Engineering }\end{array}$ & $\begin{array}{c}0.529 \\
(0.799)\end{array}$ & $\begin{array}{l}22.4 \\
(5.87)\end{array}$ & $\begin{array}{c}6.24 \\
(4.97)\end{array}$ & $\begin{array}{c}55.5 \\
(20.9)\end{array}$ \\
\hline East Asian Studies & $\begin{array}{c}0.235 \\
(0.437)\end{array}$ & $\begin{array}{l}12.4 \\
(2.23)\end{array}$ & $\begin{array}{c}5.06 \\
(2.86)\end{array}$ & $\begin{array}{c}9.12 \\
(4.24)\end{array}$ \\
\hline Econnmics & $\begin{array}{l}1.53 \\
(0.874)\end{array}$ & $\begin{array}{l}39.4 \\
(3.33)\end{array}$ & $\begin{array}{l}14.9 \\
(7.09)\end{array}$ & $\begin{array}{c}82.3 \\
(13.9)\end{array}$ \\
\hline English & $\begin{array}{c}6.65 \\
(2.34)\end{array}$ & $\begin{array}{l}34.9 \\
(2.29)\end{array}$ & $\begin{array}{c}48.4 \\
(11.0)\end{array}$ & $\begin{array}{c}96.9 \\
(13.1)\end{array}$ \\
\hline
\end{tabular}


Appandix Table $\mathrm{A}$ (continued)

\begin{tabular}{|c|c|c|c|c|}
\hline Major & $\begin{array}{l}\text { Female } \\
\text { Facalty }\end{array}$ & $\begin{array}{l}\text { Total } \\
\text { Faculy }\end{array}$ & $\begin{array}{l}\text { Female } \\
\text { Majors }\end{array}$ & rotal \\
\hline Geology & $\begin{array}{c}0.882 \\
(1.05)\end{array}$ & $\begin{array}{l}16.1 \\
(1.11)\end{array}$ & $\begin{array}{c}4.59 \\
(3.02)\end{array}$ & $\begin{array}{l}12.1 \\
(6.23)\end{array}$ \\
\hline $\begin{array}{l}\text { Cermaric Languages } \\
\text { and Literature }\end{array}$ & $\begin{array}{l}1.82 \\
(0.883)\end{array}$ & $\begin{array}{l}10.5 \\
(1.33)\end{array}$ & $\begin{array}{l}1.59 \\
(1.54)\end{array}$ & $\begin{array}{c}3.47 \\
(2.96)\end{array}$ \\
\hline History & $\begin{array}{c}4.23 \\
(1.44)\end{array}$ & $\begin{array}{l}35.6 \\
(3.49)\end{array}$ & $\begin{array}{c}41.9 \\
(12.8)\end{array}$ & $\begin{array}{l}124.0 \\
(19.6)\end{array}$ \\
\hline Mathematios & $\begin{array}{c}0.294 \\
(0.686)\end{array}$ & $\begin{array}{c}35.9 \\
(4.23)\end{array}$ & $\begin{array}{c}2.18 \\
(1.67)\end{array}$ & $\begin{array}{l}17.1 \\
(6.72)\end{array}$ \\
\hline Music & $\begin{array}{l}0.765 \\
(0.970)\end{array}$ & $\begin{array}{l}10.6 \\
(2.94)\end{array}$ & $\begin{array}{l}2.13 \\
(1.54)\end{array}$ & $\begin{array}{l}7.13 \\
(3.74)\end{array}$ \\
\hline Near Eastern Studies & $\begin{array}{c}0.471 \\
(0.624)\end{array}$ & $\begin{array}{l}12.8 \\
(2.51)\end{array}$ & $\begin{array}{l}2.47 \\
(2.58)\end{array}$ & $\begin{array}{l}5.29 \\
(3.33)\end{array}$ \\
\hline Frilosoghy & $\begin{array}{l}1.41 \\
(1.00)\end{array}$ & $\begin{array}{l}18.9 \\
(1.96)\end{array}$ & $\begin{array}{c}4.88 \\
(3.62)\end{array}$ & $\begin{array}{l}21.8 \\
(7.34)\end{array}$ \\
\hline Prysios & $\begin{array}{c}0.471 \\
(0.514)\end{array}$ & $\begin{array}{l}43.5 \\
(3.69)\end{array}$ & $\begin{array}{c}2.24 \\
(1.64)\end{array}$ & $\begin{array}{l}22.6 \\
(4.61)\end{array}$ \\
\hline Politics & $\begin{array}{l}2.94 \\
(1.39)\end{array}$ & $\begin{array}{l}33.0 \\
(4.60)\end{array}$ & $\begin{array}{c}26.7 \\
(13.4)\end{array}$ & $\begin{array}{l}86.5 \\
(21.3)\end{array}$ \\
\hline Psyctiology & $\begin{array}{c}3.18 \\
(1.63)\end{array}$ & $\begin{array}{l}20.2 \\
(1.60)\end{array}$ & $\begin{array}{l}22.8 \\
(5.74)\end{array}$ & $\begin{array}{c}54.1 \\
(12.9)\end{array}$ \\
\hline Religion & $\begin{array}{l}1.53 \\
(1.77)\end{array}$ & $\begin{array}{l}10 \\
(1.27)\end{array}$ & $\begin{array}{l}7.65 \\
(5.07)\end{array}$ & $\begin{array}{l}18.4 \\
(7.74)\end{array}$ \\
\hline $\begin{array}{l}\text { Ramanoe Languages } \\
\text { and Literature }\end{array}$ & $\begin{array}{l}5.88 \\
(3.04)\end{array}$ & $\begin{array}{l}23.0 \\
(4.14)\end{array}$ & $\begin{array}{l}10.6 \\
(3.14)\end{array}$ & $\begin{array}{l}15.0 \\
(4.24)\end{array}$ \\
\hline $\begin{array}{l}\text { Slavic Langlages } \\
\text { and Literature }\end{array}$ & $\begin{array}{l}1.35 \\
(0.702)\end{array}$ & $\begin{array}{l}4.47 \\
(0.624)\end{array}$ & $\begin{array}{c}4.53 \\
(2.21)\end{array}$ & $\begin{array}{c}6.23 \\
(2.49)\end{array}$ \\
\hline sociology & $\begin{array}{l}2.29 \\
(0.686)\end{array}$ & $\begin{array}{l}16.1 \\
(1.56)\end{array}$ & $\begin{array}{l}10.9 \\
(4.66)\end{array}$ & $\begin{array}{l}19.8 \\
(6.33)\end{array}$ \\
\hline Statistics & $\begin{array}{c}0 \\
(0)\end{array}$ & $\begin{array}{l}5.94 \\
(2.73)\end{array}$ & $\begin{array}{l}1.71 \\
(2.11)\end{array}$ & $\begin{array}{c}4.88 \\
(4.51)\end{array}$ \\
\hline
\end{tabular}

\begin{tabular}{|c|c|c|c|c|}
\hline Major & $\begin{array}{l}\text { Female } \\
\text { Faculty }\end{array}$ & $\begin{array}{l}\text { Total } \\
\text { Faculty }\end{array}$ & $\begin{array}{l}\text { Fenale } \\
\text { Kajors }\end{array}$ & $\begin{array}{l}\text { Total } \\
\text { rajors }\end{array}$ \\
\hline Geology & $\begin{array}{l}0.882 \\
(1.05)\end{array}$ & $\begin{array}{l}16.1 \\
(1.11)\end{array}$ & $\begin{array}{c}4.59 \\
(3.02)\end{array}$ & $\begin{array}{l}12.1 \\
(6.23)\end{array}$ \\
\hline $\begin{array}{l}\text { Cermanic Languages } \\
\text { and Literature }\end{array}$ & $\begin{array}{l}1.82 \\
(0.883)\end{array}$ & $\begin{array}{l}10.5 \\
(1.33)\end{array}$ & $\begin{array}{l}1.59 \\
(1.54)\end{array}$ & $\begin{array}{c}3.47 \\
(2.96)\end{array}$ \\
\hline History & $\begin{array}{c}4.23 \\
(1.44)\end{array}$ & $\begin{array}{l}35.6 \\
(3.49)\end{array}$ & $\begin{array}{c}41.9 \\
(12.8)\end{array}$ & $\begin{array}{l}124.0 \\
(19.6)\end{array}$ \\
\hline Mathenatios & $\begin{array}{c}0.294 \\
(0.686)\end{array}$ & $\begin{array}{c}35.9 \\
(4.23)\end{array}$ & $\begin{array}{c}2.18 \\
(1.67)\end{array}$ & $\begin{array}{l}17.1 \\
(6.72)\end{array}$ \\
\hline Music & $\begin{array}{l}0.765 \\
(0.970)\end{array}$ & $\begin{array}{l}10.6 \\
(2.94)\end{array}$ & $\begin{array}{l}2.13 \\
(1.54)\end{array}$ & $\begin{array}{l}7.13 \\
(3.74)\end{array}$ \\
\hline Near Eastern Studies & $\begin{array}{c}0.471 \\
(0.624)\end{array}$ & $\begin{array}{l}12.8 \\
(2.51)\end{array}$ & $\begin{array}{l}2.47 \\
(2.58)\end{array}$ & $\begin{array}{l}5.29 \\
(3.33)\end{array}$ \\
\hline Frillosophy & $\begin{array}{c}1.41 \\
(1.00)\end{array}$ & $\begin{array}{l}18.9 \\
(1.96)\end{array}$ & $\begin{array}{c}4.88 \\
(3.62)\end{array}$ & $\begin{array}{l}21.8 \\
(7.34)\end{array}$ \\
\hline Physics & $\begin{array}{c}0.471 \\
(0.514)\end{array}$ & $\begin{array}{l}43.5 \\
(3.69)\end{array}$ & $\begin{array}{l}2.24 \\
(1.64)\end{array}$ & $\begin{array}{l}22.6 \\
(4.61)\end{array}$ \\
\hline Politics & $\begin{array}{l}2.94 \\
(1.39)\end{array}$ & $\begin{array}{l}33.0 \\
(4.60)\end{array}$ & $\begin{array}{c}26.7 \\
(13.4)\end{array}$ & $\begin{array}{l}86.5 \\
(21.3)\end{array}$ \\
\hline Psyctology & $\begin{array}{l}3.18 \\
(1.63)\end{array}$ & $\begin{array}{l}20.2 \\
(1.60)\end{array}$ & $\begin{array}{l}22.8 \\
(5.74)\end{array}$ & $\begin{array}{l}54.1 \\
(12.9)\end{array}$ \\
\hline Religion & $\begin{array}{l}1.53 \\
(1.77)\end{array}$ & $\begin{array}{l}10 \\
(1.27)\end{array}$ & $\begin{array}{l}7.65 \\
(5.07)\end{array}$ & $\begin{array}{l}18.4 \\
(7.74)\end{array}$ \\
\hline $\begin{array}{l}\text { Ramance Languages } \\
\text { and Literature }\end{array}$ & $\begin{array}{l}5.88 \\
(3.04)\end{array}$ & $\begin{array}{l}23.0 \\
(4.14)\end{array}$ & $\begin{array}{l}10.6 \\
(3.14)\end{array}$ & $\begin{array}{l}15.0 \\
(4.24)\end{array}$ \\
\hline $\begin{array}{l}\text { Slavic Languages } \\
\text { and Literature }\end{array}$ & $\begin{array}{l}1.35 \\
(0.702)\end{array}$ & $\begin{array}{l}4.47 \\
(0.624)\end{array}$ & $\begin{array}{c}4.53 \\
(2.21)\end{array}$ & $\begin{array}{c}6.23 \\
(2.49)\end{array}$ \\
\hline sociology & $\begin{array}{l}2.29 \\
(0.686)\end{array}$ & $\begin{array}{l}16.1 \\
(1.56)\end{array}$ & $\begin{array}{l}10.9 \\
(4.66)\end{array}$ & $\begin{array}{l}19.8 \\
(6.33)\end{array}$ \\
\hline Statistics & $\begin{array}{c}0 \\
(0)\end{array}$ & $\begin{array}{c}5.94 \\
(2.73)\end{array}$ & $\begin{array}{c}1.71 \\
(2.11)\end{array}$ & $\begin{array}{c}4.88 \\
(4.51)\end{array}$ \\
\hline
\end{tabular}

"Source: See Table 2a. The first colum shows the average number of fenale faculty in the department over the period 1973-1989; the second colum is the average number of total faculty; the thind colum is the average number of female majors; and the fourth column is the average number of total majors. Figures in parentheses are standard deviatians. 
rajor

Aerospace Engineering

Anthropology

Art and Archaeology

Astronany

Atmospheric and cosaric Science

Biology
Cremical Engineering
Cremistry
Civil ard Enviromental
Engineering
Classics

-

commiation

East Asian Stadies

Econamios

Electrical Engineering and camputer science

English
Appendix Table B 8umary I ovels Data*
oniversity of kichigan

Femalo

Faculty

Total

Faculty

Female
Yinjors

0.667

$(0.492)$

23.5

(1.17)

4.08

(1. 24)

19.3

(3.31)

4.5

(1.0)

14.9

(2.15)

0

(0.)

9.42

(0.515)

16.3

(1.07)

(0)

44.3

(4.71)

16.9

(1.08)

35.0

$(2.45)$

24.5

(1.)

13.8

(1.03)

2.67

$(0.888)$

(1.03)

2.25

(1.06)

12.3

(2.64)

2.08

$(0.900)$

10.4

(2.07)

1.92

$(0.793)$

34.3

(3.36)

2.92

(1.56)

65.6

(13.4)

8.75

$(2.22)$

61.0

(3.49)
13.

(6.83)

33.8

(11.4)

28.0

(11.2)

0.250

$(0.452)$

4.0

(2.45)

129.0

(16.9)

27.9

(7.49)

19.3

(4.29)

17.8

(12.6)

4.58

(2.64)

118.0

(36.7)

10.8

$(8.54)$

100.0

(23.6)

66.0

(23.0)

169.0

(62.0)
Total

yajora

114

(37.7)

57.0

(16.1)

34.5

(12.8)

4.58

(1.83)

13.8

(4.22)

322.0

(24.6)

115.0

(35.1)

72.8

(17.9)

65.8

(29.9)

8.0

(3.93)
175.4

(51.1)

20.6

(12.6)

297

(43.0)

415.0

(84.6)

277.0

(91.0) 
Appeindtr Table B (continued)

\begin{tabular}{|c|c|c|c|c|}
\hline Major & Faculty & Facullty & Majors & Majors \\
\hline Geoløy & $\begin{array}{c}0.167 \\
(0.389)\end{array}$ & $\begin{array}{l}17.0 \\
(1.95)\end{array}$ & $\begin{array}{c}5.40 \\
(3.37)\end{array}$ & $\begin{array}{l}11.9 \\
(5.11)\end{array}$ \\
\hline $\begin{array}{l}\text { Germanic Languages } \\
\text { and Literature }\end{array}$ & $\begin{array}{l}3.75 \\
(0.965)\end{array}$ & $\begin{array}{l}17.3 \\
(2.10)\end{array}$ & $\begin{array}{l}11.9 \\
(5.32)\end{array}$ & $\begin{array}{l}19.4 \\
(8.53)\end{array}$ \\
\hline History & $\begin{array}{c}4.91 \\
(2.02)\end{array}$ & $\begin{array}{l}44.5 \\
(3.12)\end{array}$ & $\begin{array}{c}50.2 \\
(13.3)\end{array}$ & $\begin{array}{l}133.0 \\
(43.4)\end{array}$ \\
\hline $\begin{array}{l}\text { Industrial and operations } \\
\text { Engineering }\end{array}$ & $\begin{array}{l}0.750 \\
(0.754)\end{array}$ & $\begin{array}{l}16.5 \\
(3.37)\end{array}$ & $\begin{array}{c}40.7 \\
(12.5)\end{array}$ & $\begin{array}{l}115.0 \\
(22.0)\end{array}$ \\
\hline Linguistios & $\begin{array}{l}3.42 \\
(0.793)\end{array}$ & $\begin{array}{l}11.8 \\
(3.25)\end{array}$ & $\begin{array}{l}7.16 \\
(4.24)\end{array}$ & $\begin{array}{c}9.92 \\
(5.25)\end{array}$ \\
\hline $\begin{array}{l}\text { Materials Science and } \\
\text { Engineering }\end{array}$ & $\begin{array}{c}0 \\
(0)\end{array}$ & $\begin{array}{l}11.6 \\
(2.02)\end{array}$ & $\begin{array}{c}8.83 \\
(4.76)\end{array}$ & $\begin{array}{l}31.6 \\
(7.61)\end{array}$ \\
\hline Mathematios & $\begin{array}{l}1.83 \\
(0.718)\end{array}$ & $\begin{array}{l}59.6 \\
(3.06)\end{array}$ & $\begin{array}{c}27.8 \\
(13.2)\end{array}$ & $\begin{array}{c}65.2 \\
.(20.3)\end{array}$ \\
\hline Mechanical Engineering & $\begin{array}{l}1.33 \\
(1.23)\end{array}$ & $\begin{array}{l}45.2 \\
(4.06)\end{array}$ & $\begin{array}{c}34.9 \\
(12.4)\end{array}$ & $\begin{array}{l}240.0 \\
(50.9)\end{array}$ \\
\hline $\begin{array}{l}\text { Naval and Marine } \\
\text { Engineering }\end{array}$ & $\begin{array}{c}0 \\
(0)\end{array}$ & $\begin{array}{l}11.6 \\
(1.08)\end{array}$ & $\begin{array}{l}1.58 \\
(1.51)\end{array}$ & $\begin{array}{c}40.5 \\
(18.6)\end{array}$ \\
\hline Near Eastern Stardies & $\begin{array}{l}1.17 \\
(0.389)\end{array}$ & $\begin{array}{l}17.0 \\
(0.739)\end{array}$ & $\begin{array}{l}2.25 \\
(1.48)\end{array}$ & $\begin{array}{c}4.92 \\
(2.23)\end{array}$ \\
\hline Nuclear Engineering & $\begin{array}{c}0.50 \\
(0.522)\end{array}$ & $\begin{array}{l}13.2 \\
(1.19)\end{array}$ & $\begin{array}{c}2.08 \\
(1.51)\end{array}$ & $\begin{array}{l}19.0 \\
(5.26)\end{array}$ \\
\hline Philosophy & $\begin{array}{l}1.00 \\
(0.603)\end{array}$ & $\begin{array}{l}14.8 \\
(1.75)\end{array}$ & $\begin{array}{l}12.2 \\
(5.80)\end{array}$ & $\begin{array}{c}37.1 \\
(14.2)\end{array}$ \\
\hline Physics & $\begin{array}{r}0.0833 \\
(0.289)\end{array}$ & $\begin{array}{l}50.2 \\
(2.59)\end{array}$ & $\begin{array}{c}3.75 \\
(1.54)\end{array}$ & $\begin{array}{l}37.5 \\
(5.93)\end{array}$ \\
\hline Political Science & $\begin{array}{c}4.33 \\
(1.67)\end{array}$ & $\begin{array}{l}32.9 \\
(2.50)\end{array}$ & $\begin{array}{l}101.0 \\
(22.1)\end{array}$ & $\begin{array}{l}240.0 \\
(54.9)\end{array}$ \\
\hline Psychology & $\begin{array}{l}10.6 \\
(3.52)\end{array}$ & $\begin{array}{l}51: 5 \\
(6.88)\end{array}$ & $\begin{array}{l}247.0 \\
(52.0)\end{array}$ & $\begin{array}{l}358.0 \\
(71.0)\end{array}$ \\
\hline
\end{tabular}

$\begin{array}{llll}\text { Female } & \text { Total } & \text { Female } & \text { Total } \\ \text { Faculty } & \text { Faculty } & \text { Majors } & \text { Majors }\end{array}$


Appondix Table B (continued)

\section{Major}

\begin{tabular}{|c|c|c|}
\hline $\begin{array}{l}\text { Female } \\
\text { Faculty }\end{array}$ & $\begin{array}{l}\text { Total } \\
\text { Faculty }\end{array}$ & $\begin{array}{l}\text { Feralo } \\
\text { Kajors }\end{array}$ \\
\hline
\end{tabular}

Romance Languages and
Literature
Slavic Languages and
and Literature
sociology
Statistics

$\begin{array}{cl}5.92 & 27.8 \\ (0.793) & (2.93) \\ 1.58 & 10.6 \\ (0.515) & (0.793) \\ 3.92 & 24.4 \\ (2.02) & (3.20) \\ 0.167 & 9.42 \\ (0.577) & (1.24)\end{array}$

32.3

(12.7)

40.7

(15.1)

10.3

$(6.08)$

20.8

(10.7)

29.0

(13.1)

41.6

(19.0)

4.17

(3.40)

10.2

6.16

* Source: See Table Ib. Computations are the same as in Appendix Table A, except the time period is 1979-1990. 


\begin{tabular}{|c|c|c|c|c|}
\hline & \multicolumn{2}{|c|}{$\begin{array}{l}\text { Appendix Table C } \\
\text { oumary Iovels Data" } \\
\text { mittiler college }\end{array}$} & \multirow{3}{*}{$\begin{array}{l}\text { Ferale } \\
\text { Majors }\end{array}$} & \multirow{3}{*}{$\begin{array}{l}\text { Total } \\
\text { Majors }\end{array}$} \\
\hline & $\begin{array}{l}\text { Peanele } \\
\text { Faculty }\end{array}$ & $\begin{array}{l}\text { Total } \\
\text { Faculty }\end{array}$ & & \\
\hline \multicolumn{3}{|l|}{ Kajor } & & \\
\hline Art & $\begin{array}{l}0.308 \\
(0.630)\end{array}$ & $\begin{array}{l}1.31 \\
(0.630)\end{array}$ & $\begin{array}{c}1.85 \\
(2.15)\end{array}$ & $\begin{array}{c}2.84 \\
(2.82)\end{array}$ \\
\hline Biology & $\begin{array}{l}1.23 \\
(0.832)\end{array}$ & $\begin{array}{l}4.77 \\
(0.439)\end{array}$ & $\begin{array}{c}9.85 \\
(3.43)\end{array}$ & $\begin{array}{l}26.0 \\
(11.0)\end{array}$ \\
\hline Business Administration & $\begin{array}{c}0.231 \\
(0.439)\end{array}$ & $\begin{array}{c}4.92 \\
(1.80)\end{array}$ & $\begin{array}{l}14.7 \\
(5.04)\end{array}$ & $\begin{array}{l}47.1 \\
(11.9)\end{array}$ \\
\hline onemistry & $\begin{array}{c}0.308 \\
(0.480)\end{array}$ & $\begin{array}{l}4.77 \\
(0.439)\end{array}$ & $\begin{array}{l}2.0 \\
(1.53)\end{array}$ & $\begin{array}{c}6.38 \\
(4.35)\end{array}$ \\
\hline English & $\begin{array}{l}2.23 \\
(0.599)\end{array}$ & $\begin{array}{l}5.08 \\
(0.494)\end{array}$ & $\begin{array}{c}5.85 \\
(4.02)\end{array}$ & $\begin{array}{l}8.38 \\
(4.89)\end{array}$ \\
\hline $\begin{array}{l}\text { Foreign Languages and } \\
\text { Literature }\end{array}$ & $\begin{array}{l}1.23 \\
(0.725)\end{array}$ & $\begin{array}{l}2.69 \\
(0.480)\end{array}$ & $\begin{array}{c}3.23 \\
(2.05)\end{array}$ & $\begin{array}{c}3.69 \\
(2.53)\end{array}$ \\
\hline Geology & $\begin{array}{c}0.384 \\
(0.506)\end{array}$ & $\begin{array}{l}2.23 \\
(0.439)\end{array}$ & $\begin{array}{c}0.538 \\
(0.776)\end{array}$ & $\begin{array}{l}1.85 \\
(1.34)\end{array}$ \\
\hline History & $\begin{array}{c}0 \\
(0)\end{array}$ & $\begin{array}{l}4.61 \\
(0.660)\end{array}$ & $\begin{array}{c}2.69 \\
(1.93)\end{array}$ & $\begin{array}{c}6.69 \\
(5.12)\end{array}$ \\
\hline Hame Ecananias & $\begin{array}{l}2.38 \\
(0.650)\end{array}$ & $\begin{array}{l}2.38 \\
(0.650)\end{array}$ & $\begin{array}{l}8.31 \\
(3.50)\end{array}$ & $\begin{array}{c}8.54 \\
(3.15)\end{array}$ \\
\hline Mathematics & $\begin{array}{c}0.231 \\
(0.439)\end{array}$ & $\begin{array}{l}4.23 \\
(0.832)\end{array}$ & $\begin{array}{c}2.08 \\
(1.61)\end{array}$ & $\begin{array}{c}4.62 \\
(2.06)\end{array}$ \\
\hline Music & $\begin{array}{l}1.46 \\
(0.776)\end{array}$ & $\begin{array}{l}3.69 \\
(0.630)\end{array}$ & $\begin{array}{c}2.46 \\
(1.90)\end{array}$ & $\begin{array}{c}4.0 \\
(2.89)\end{array}$ \\
\hline Philosoghy & $\begin{array}{c}0 \\
(0)\end{array}$ & $\begin{array}{c}2.23 \\
(0.599)\end{array}$ & $\begin{array}{c}0.308 \\
(0.480)\end{array}$ & $\begin{array}{c}0.769 \\
(1.30)\end{array}$ \\
\hline Prysical Ectucation & $\begin{array}{l}1.0 \\
(0.913)\end{array}$ & $\begin{array}{l}4.08 \\
(0.954)\end{array}$ & $\begin{array}{c}5.0 \\
(2.27)\end{array}$ & $\begin{array}{l}15.5 \\
(4.79)\end{array}$ \\
\hline Prysics & $\begin{array}{c}0 \\
(0)\end{array}$ & $\begin{array}{l}1.0 \\
(0)\end{array}$ & $\begin{array}{c}0 \\
(0)\end{array}$ & $\begin{array}{r}0.923 \\
(1.11)\end{array}$ \\
\hline Political science & $\begin{array}{c}0.615 \\
(0.650)\end{array}$ & $\begin{array}{c}5.62 \\
(0.961)\end{array}$ & $\begin{array}{c}6.85 \\
(1.77)\end{array}$ & $\begin{array}{l}23.2 \\
(7.43)\end{array}$ \\
\hline
\end{tabular}


Appandix Tablo C (contirued)

kajor

$\begin{array}{lll}\text { Perale Total } & \text { Female } & \text { Total } \\ \text { Faculty } & \text { Faculty } & \text { Kajora }\end{array}$

Psychology

$$
\begin{aligned}
& 1.92 \\
& (0.641)
\end{aligned}
$$

Religion

0

(0)

$$
5.54
$$

(0.967)

10.7

(6.18)

16.4

1.85

(0.689)

0.231

(0.599)

(9.99)

1.38

(0.506)

3.62

(0.506)

9.0

$(7.0)$

0.692

(1.18)

0.231

4.54

(0.519)

10.2

(5.18)

13.1

(9.73)

13.1

(6.01)

* Source: See Table 1c. Cuputations are the same as in Appendix Table A, except the time period is 1974-1986. 
REFERENCES

Anderson, Roberta T. and Pauline Ramsey, "Women in Higher Echoation: Develagnent thraugh Acministrative Mentoring," in Welsh, Lynne B. (ed.), Women in Higher Education: Changes and Challenges. New York: Praeger, 1990, pp. 283-285.

Barron's Educational Series, Incorporated, Bancon's proftles of American Colleges, 19th edition. United States of America: Barron's Educational Series, 1992.

Betz, Nancy E. and Lauise F. Fitzgerald, The career Psychology of Women. Orlando, Florlda: Academic Press, Inc., 1987.

Corcoran, Mary E. and Paul N. Courant, "Sex Role Soclalization and Iabor Market Outocmes," American Econamic Review, May 1985, pp. 275-278.

Davan, Elizabeth, "The Role of Models in Women's Professional Develogment," Psyctolocy of Wamen quarterly, Fall 1976, pp. 5-15.

Enrenberg, Ronald G., "The Flow of New Doctorates," Jammal of Econamic Literature, June 1992, pp. 830-875.

Fox, Greer Litton, "Scme observations and Data on the Availabllity of Role Models as a Factor in Undergraduate Career cholo," soctological Foass, Fall 1974, pp. 15-30.

Furlang, Andy, "School and Female Doapational Aspiratians," British Jaumal of Sociolocr of suluation, December 1986, pp. 369-375. 
Girgus, Joan S. et al., program for Recruitment and Retention of women Faalty in Science and Engineering: A Report to the Dean of Faculty Robert C. Gunging, mimeo, Princeton University, February 1992.

Gross, James A., Teachers on Trial. Ithaca: IIR Press, 1988.

Hackett, Gain, Donna Esposito and M. Sean O'Halloran, "The Relationship of Role Model Influenoes to the Career Salience and Etucational and Career Plans of college Wamen," Joungal of Vocational Behavior 35, 1989, pp. $164-180$.

Lafortume, Louise, "On Being a Woman and Sturying Math," In Cosztonyi, Marianne (ed.), Despite the Odds: Essays on canadian women and scilenoe. Montreal: Vehiaule Press, 1990, pp. 265-271.

Maddala, G.S., Limited-Dependent and Qualitative Variables in Econometrics. Cambridge: Cambridge University Press, 1983.

Manegold, Catherine S., "Fewer Men Eam Doctorates, Particularly Arong Blacks," York Times, January 18, 1994, p. A14.

Rothstein, Dorra S., "Do Female Faculty Influence Female Students' Subsequent Educational and Labor Market Attainments?" Norking Paper, Cornell University, 1994.

Swith, Walter S. and Thamas oven Erb, "Effect of Wamen in Sclence Career Role Models on Early Adolescents'," Attitudes Toward Scientists and Women in Sclence," Jamal of Research in Scilence Teaching 23, no. 8, Novenber 1986, pp. $667-676$. 
Tilghman, Shirley M., "Science vs. the Female Scientist," New York Times, 25 Jaruary 1993, p. Al7. 


\section{Endootes}

1. This argument is also made in the context of race. Thus, a sociologist argued that the dearth of black males receiving doctoral degrees is because "young blacks have no real role models" (Manegold [1994, p.A14]).

2. For further assertions along these lines, see furlang [1986] and Douvan [1976].

3. Academic divisions are groupings of departments. There are five in Fox's study: social scienoes, natural sciences, muandtles, ectucation, and applied sclences.

4. Mre generally, Gross [1988, p.24] argues that there is no elpirical evidence that pre-college students emulate any aspects of their teachers' canduct.

5. Econcmists appear not to have dealt with this issue very much. For example, Errenberg's [1992] excellent survey on the flows of indivituals into

acadenic specialties reports no research on this topic.

6. These Inclualed the University of virginia, the University of North Carolina at chapel Hill, the University of Wachington in Seattle, Loyola college in Ios Angeles, Duke University, and Syracuse university.

7. See Barron's Edrational Series, Inc. [1992] for information on acmissians standards. 
8. The lists included the students' middle names. Hence, even in cases where students had androgynous first names, it was possible to determine their gender.

9. However, when we analyzed the data for the earlier period, we found that the substantive conclusions were essentially the same as those reported below.

10. The Princeton and Michigan data include every departiment in those institutions. The whittier data include every department except anthropology, which ceased being a department there curing arr sample period. Corresponding data on the levels (as apposed to proportions) of fenale students and faculty are exhibited in the Appendix Tables.

11. For Princeton, the coefficient was 1.527 (s.e. $=0.340$ ); for Michigan 2.182 (s.e. $=0.344$ ); and for hinittier 0.665 (s.e. $=0.164$ ).

12. In computing FACFEM $_{1 t}$, the following conventions were used to deal with joint appointments. For Prinoton and whittier, we assumed that a member of two departments could serve as a role model in each of those departments. Hence, faculty with joint appolntments were in effect double-counted. For Michigan, however, we were provided no information on joint appolntments. The office that compiled the data assigned faculty members to the department in which they spent most of their time.

13. Other definitians are examined in Section 4.3 belaw. 
14. Each of our institurtions allowed modest mubers of transfer students. In principle it would have been desirable to remove them fram the sample, because there is little reason to believe that their decisions oould be affected by faoulty gender composition at a time when they weren't even on campus. However, our data did not allow us to identify them. We doubt if this phenomeron seriausly affects our results, although it would clearly be worthwile to investigate it if suitable data become available.

15. This specification assumes that, within a sctool, the $\beta_{q}$ 's are constant across departments, a hypothesis that could not be rejected in our data. Also, the specification assumes that an increase in the proportion of female faculty is independent of the size of the department's faculty. However, when we interacted FAcFay, with department size, the results reported below did not change. Finally, note that the mmber of grachuting majors in a department is the product of the number of students who initially choose the major and the retention rate. our data do not allow us to separate the two.

16. We also estimated the equation with time effects (a different intercept for each year) rather than a quadratic time trend. The substantive results were substantially the same. Note that including total female undergrachates as an explanatory variable would be equivalent to the use of year durmy variables.

17. The $F(29,522)$ statistic for the joint mypothesis that all the coefficients are zero is 28.17; the critical value at the 0.05 significance level is 1.46 . 
18. For Michigan, a test of the hypothesis that the coefficients are jointly insignificant generates an $F(33,435)$ statistic of 56.3 . For Whittier, the F $(18,229)$ statistic is 87.59 . In both cases, the statistic far exceeds the critical value at the 0.05 significance level.

19. The fact that our left-hand side variable is a proportion creates two concerns. First, econometric problems may arise when a left-hand side variable cannot be greater than one or less than zero. We therefore reestimated the model using a variant of the logit transformation suggested by Maddala [1983, p.30]. (The corventional logit transformation is not appropriate because $5 T \mathrm{FEM}_{\mathrm{it}}$ sametimes equals one or zero. In the variant, a factor depending on the rumber of observations in the cell is added to each sample proportion, so that it is never necessary to.take the log of zero.) The results were qualitatively the same as those discussed above. Second, perhaps the results might change if the equation were estimated in levels rather than proportions. We therefore estimated equation (1) replacing STUFEM, and FACFEM, with the corresponding levels, and augmenting the equation with the total number of students to control for scale effects. The results are qualitatively the same as those reported above, except the coefficient on female faculty at Princeton goes fram insignificant positive to insignificant negative.

20. When a 20 percent threshold is used, the Michigan cofficient remains negative and significant and the Princeton and Whittier coefficients remain insigntficant. With a threshold of 10 percent, the Michigan cofficient remains negative and significant, but Princeton's positive cofficient becomes significant, with a t-statistic of 2.1. Iike the negative Michigan coeficient, however, it is small in absolute value $(0.0475)$. 
21. For Princetan, $\beta_{i}^{\prime \prime}$ and $\beta_{4}$ are jointly significant only at a 0.38 significance level, for Michigan at a 0.12 significance level, and Whittier at a 0.58 significance level.

22. For this specification, SIZE $\mathrm{it}_{\mathrm{i}}$ is computed as the average of sizes when the graduates of year $t$ were first- and second-year students.

23. We classified the following departments as being in the humanities and social sciences: Anthropology, Architecture, Art and Archaeology, Business Administration, Classios, Commication, Comparative Literature, East Asian Studies, Econcmics, English, Foreign Languages and Literature, Germanic Languages and Literature, Home Economlos, History, Lingulstios, Music, Near Eastern Studies, Fhilosophy, Prysical Education, Polltics, Psychology, Religion, Romance Languages and Literature, Slavic Languages and Literature, Sociology, Speech. The scienoes are: Aerospace and Mechanical Engineering, Astronary, Astrophysical Sciences, Atmospheric and Doearic science, Biology, Chenical Engineering, Chemistry, civil and Enviranmental Engineering, Camputer science and Electrical Engineering, Inchustrial and operations Engineering, Mathematios, Naval and Marine Engineering, Muclear Engineering, and Statistics.

24. An F-test of the hypothesis that the three schools have the same coefficient on FACFEM/s (canditional on the other coefflcients varying by school) yields an $F(2,1086)$ test statistic of 2.15 , which is signifloant at the 0.12 level. Hence, this type of pooling is cansistent with the data. 